UDC 37.04

\title{
Model of realization of personalized learning of students of higher education institution
}

\author{
Tkachuk H. V. * \\ Pavlo Tychyna Uman State Pedagogical University, Uman, Ukraine
}

Received: 12.07 .2021

Accepted: 24.09 .2021

\begin{abstract}
In the article, the author considers the organization of personalized learning of students of higher education by designing a pedagogical model of education. Personalized learning improves the educational process, as the student can build their own educational trajectory according to their individual needs, interests, preferences, and abilities. The proposed pedagogical model reveals the structure and content of personalized education of higher education institutions, the central figure of which is the student, his educational needs, interests, and abilities. We have identified the purpose of personalized learning, the principles and main stages that reflect the dynamics of its operation, as well as the pedagogical conditions for effective implementation of the proposed model. We have identified the basic principles of personalized learning. These are the principle of consciousness and activity of the student, accessibility and comprehensibility of the content of education, flexibility and adequacy of the educational process, the principle of consistency and dosage of educational content, social participation of participants in the educational process, control and self-control. The implementation of the model should be carried out in stages. These processes include the processes of initiation, diagnosis, and design, integration, with the latter process occurring cyclically. Pedagogical conditions are the main condition for the effectiveness of personalized learning. In the process of implementing personalized learning, it is advisable to adhere to the normative, socio-psychological, and organizational-pedagogical conditions of the educational process. The development of the model made it possible to identify certain characteristics of personalized learning. In particular, it allows to significantly increase the motivation to learn, to build an individual educational trajectory, to adapt the learning process in accordance with the student's interactions and through the mechanisms of electronic environment systems.
\end{abstract}

Key words: personalized learning, adaptive learning, learning model, pedagogical conditions, educational environment, university.

\section{Модель реалізації персоналізованого навчання студентів закладу вищої освіти}

\author{
Ткачук Г. В. \\ Уманський державний педагогічний університет імені Павла Тичини, Умань, Україна
}

\begin{abstract}
Анотація. В статті розглядається питання організації персоналізованого навчання студентів закладу вищої освіти шляхом проєктування педагогічної моделі навчання. 3'ясовано, що персоналізоване навчання дає змогу удосконалити освітній процес, побудувати освітню траєкторію навчання студента у відповідності з його індивідуальними освітніми потребами, інтересами, вподобаннями і здібностями. У пропонованій нами педагогічній моделі розкривається структура і зміст персоналізованого навчання закладів вищої освіти, центральною фігурою якої $є$ студент, його освітні потреби, інтереси та задатки. Нами визначено ціль реалізації персоналізованого навчання, принципи та основні етапи, що відображають динаміку його функціонування, а також педагогічні умови ефективної реалізації пропонованої моделі. Серед основних принципів, які визначають логіку персоналізованого навчання визначено принцип свідомості та активності студента, доступності та зрозумілості змісту освіти, гнучкості та адекватності освітнього процесу, принцип послідовності та дозованості освітнього контенту, соціальної участі учасників освітнього процесу, контролю та самоконтролю. Реалізацію моделі доцільно здійснювати поетапно, що включає процеси ініціювання, діагностики та проєктування, інтеграції, при чому останній процес відбувається постійно. В роботі також визначено педагогічні умови, які $€$ головною умовою ефективності персоналізованого навчання. У процесі
\end{abstract}

Corresponding Author: Tkachuk Halyna Volodymyrivna. Phone: +380969169399. E-mail: tkachuk.g.v@udpu.edu.ua Pavlo Tychyna Uman State Pedagogical University, 28 Sadova str., Uman, Cherkassy region, Ukraine, 20300

Biдnовідальний автор: Ткачук Галина Володимирівна. Тел. +380969169399. E-mail: tkachuk.g.v@udpu.edu.ua Уманський державний педагогічний університет імені Павла Тичини, вул. Садова, Умань, 20300 
реалізації персоналізованого навчання доцільно дотримуватись нормативно-змістових, соціальнопсихологічних та організаційно-педагогічних умов забезпечення освітнього процесу. Розробка моделі дала змогу виявити певні характеристики персоналізованого навчання. Зокрема, воно дає змогу значно підвищити мотивацію до навчання, побудувати індивідуальну освітню траєкторію, адаптувати навчальний процес у відповідності до взаємодій студента та за допомогою механізмів систем електронного середовища.

Ключові слова: персоналізоване навчання, адаптивне навчання, модель навчання, педагогічні умови, інформаційно-освітнє середовище, заклад вищої освіти.

\title{
Модель реализации персонализированного обучения студентов учреждения высшего образования
}

\author{
Ткачук Г. В. \\ Уманский государственный педагогический университет имени Павла Тычины, Умань, Украина
}

\begin{abstract}
Аннотация. В статье рассматривается вопрос организации персонализированного обучения студентов учреждения высшего образования с помощью проектирования педагогической модели обучения. Выяснено, что персонализированное обучение позволяет усовершенствовать образовательный процесс, построить образовательную траекторию обучения студента в соответствии с его индивидуальными образовательными потребностями, интересами, склонностями и способностями. В предлагаемой нами педагогической модели раскрывается структура и содержание персонализированного обучения высших учебных заведений, центральной фигурой которой является студент, его образовательные потребности, интересы и способности. Нами определены цель реализации персонализированного обучения, принципы и основные этапы, отражающие динамику его функционирования, а также педагогические условия эффрективной реализации предлагаемой модели. Среди основных принципов, определяющих логику персонализированного обучения определен принцип сознания и активности студента, доступности и понятности содержания образования, гибкости и адекватности образовательного процесса, принцип последовательности и дозированности образовательного контента, социального участия участников образовательного процесса, контроля и самоконтроля. Реализацию модели целесообразно осуществлять поэтапно, которая включает процессы инициирования, диагностики и проектирования, интеграции. При этом последний этап происходит постоянно. В работе также определены педагогические условия, которые являются главным условием эффрективности персонализированного обучения. В процессе реализации персонализированного обучения целесообразно придерживаться нормативно-содержательных, социально-психологических и организационно-педагогических условий обеспечения образовательного процесса. Разработка модели позволила выявить определенные характеристики персонализированного обучения. В частности, оно позволяет значительно повысить мотивацию к обучению, построить индивидуальную образовательную траекторию, адаптировать учебный процесс посредством взаимодействий студента и с помощью механизмов систем электронной среды.

Ключевые слова: персонализированное обучение, адаптивное обучение, модель обучения, педагогические условия, информационно-образовательная среда, учреждение высшего образования.
\end{abstract}

\section{Bcmyn}

Успішний саморозвиток особистості, задоволення його освітніх інтересів, вікових особливостей та індивідуальних потреб прямо залежить від того наскільки ефективно організовано освітній процес. Традиційне навчання, при якому викладач формує та надає навчальний матеріал та стандартні завдання, а студенти його опрацьовують і відтворюють нині не $є$ ефективним. Ми продовжуємо сповідувати освітню культуру, при якій студент вчиться за стандартною для всіх програмою, опрацьовує однаковий матеріал, виконує однакові практичні завдання та підлягає оцінці через стандартний набір тестів та контрольних завдань. Проте, розвиток технологій, поява нових методів пізнання та складність і невизначеність у світі загалом стимулює до переосмислення традиційної ролі суб'єктів освітнього процесу, перегляд цілей та змісту навчання, удосконалення методів контролю та зворотного зв'язку.

Головною відмінністю персоналізованого навчання $€$ те, що весь навчальний процес, його методи, технології та стилі спрямовані на індивідуальність студента і адаптовані до його інтересів [3, c.171, 4]. В сфрері онлайнового бізнесу, купівлі та продажу - ця технологія давно і успішно використовується. Якщо користувач щось шукає, то система підлаштовується під цей пошук за допомогою таких механізмів як розумні оголошення, системи рекомендацій, рекламні товари [11]. 
Система пропонує користувачу альтернативні варіанти пошуку та забезпечує більш адаптований до його потреб результат.

Питання впровадження персоналізованого навчання також набуває актуальності у зв'язку 3 використанням у закладах вищої освіти (3ВО) змішаної форми навчання, коли окремі види навчальної діяльності студента можуть бути організовані в електронному інформаційно-освітньому середовищі (IOC). В даному контексті виникають проблеми щодо організації персоналізованого навчання студента в IOC, процентного співвідношення діяльності студента в IOC та в аудиторії, контролю за такою діяльністю тощо.

Мета роботи: розробити та описати модель персоналізованого навчання студентів закладу вищої освіти, в якій передбачити мету, принципи, основні етапи та педагогічні умови впровадження персоналізованого навчання.

\section{II Матеріал і методи дослідження}

Для вивчення питання персоналізованого навчання було проведено аналіз вітчизняних і зарубіжних праць та використано такі методи наукового дослідження як аналіз, синтез, інтерпретація. Для побудови моделі персоналізованого навчання було використано метод педагогічного моделювання.

В ході аналізу наукових робіт було виявлено, що у 2009 році Національна інженерна академія назвала розвиток персоніфікованих освітніх систем «Grand Challenge» 21 століття (великим викликом) поряд з такими напрямами дослідження як зворотне проєктування мозку та віртуальна реальність [17]. Нині спостерігаємо збільшення інтересу до персоналізованого навчання як ефективної методології організації освітнього процесу.

Питання персоналізованого навчання розглядається у працях багатьох учених. Розширений пошук у Google Академії за весь період і за точною фразою українською мовою «персоналізоване навчання» знайдено 209 результатів, англійською мовою «personalized learning» - 43300 (пошук станом на 1.07.2021 р.).

Ми побудували діаграму (рис. 1), в якій показано результати пошуку у відсотковому співвідношенні за роками та за точною фразою українською та англійською мовами. Як видно 3 діаграми, проблема персоналізованого навчання активно розглядається у наукових колах і з кожним роком інтерес до неї зростає.

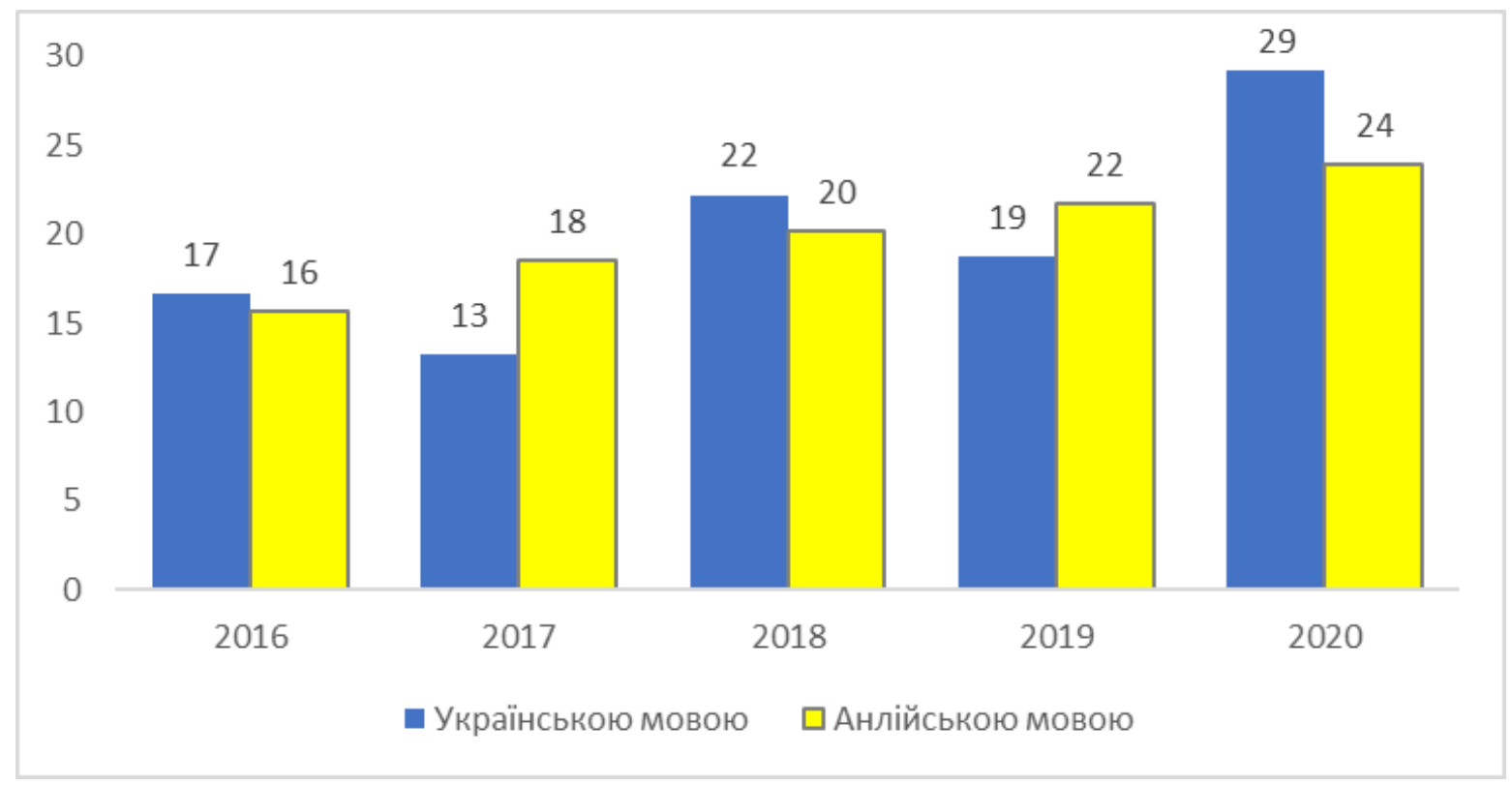

Рис. 1. Співвідношення пошукових запитів терміну «персоналізоване навчання» за останні 5 років

Звісно, що машинний пошук не дає об'єктивних результатів, але статистику зростання популярності даного терміну все ж таки можна відстежити. 
Ми проаналізували найбільш відповідні до нашої проблеми праці. Серед українських учених, доцільно відмітити роботи: В. Кухаренка, який досліджував персоналізоване навчання та модель 70:20:10 (поєднання неформального, соціального та формального навчання) [3]; С. Якубова, який розглянув проблему створення організаційно-педагогічних умов для переходу до персоналізованого навчання на основі впровадження змішаного (очно-дистанційного) навчання в освітній процес [6]; 0. Баранова та В. Артюх, які проаналізували теорії, концепції та підходи персоналізації, окремо зупинившись на принципі локалізації змісту навчального матеріалу [1]; В. Дем'яненка, який проаналізував тенденції розвитку адаптивних освітніх систем та освітні сервіси персоналізованого навчання [2]; К. Осадчої, В. Осадчого, О. Спіріна, В. Круглика, які проаналізували засоби та інструментарій підтримки індивідуалізації й персоналізації навчання у системі дистанційного навчання Moodle та здійснили короткий огляд досліджень з 2010 по 2019 р. щодо персоналізованого та адаптивного навчання з використанням IКТ [5, 20]; Г. Пуляєва, Л.Кравцова, ҐТ.Зайцева вивчили питання персоналізованого навчання студентів на основі платформи електронного навчання Moodle [21].

Серед зарубіжних учених відмітимо М. Бернацькі (M. Bernacki) та К. Уолкінгтон (C. Walkington), які вивчали роль ситуативного інтересу в персоналізованому навчанні математики [23]; Б. Брей (В.Вray) і К. Маккласкі (K.McClaskey), які у своїй роботі акцентують увагу на різниці між індивідуалізованим, диференційованим і персоналізованим навчанням і вважають, що тільки за умов персоналізованого навчання студент стає активним учасником навчання: разом із учителем визначає свої освітні цілі, бере на себе відповідальність за організацію та зміни в навчанні, створює власне навчальне середовище [12]; Труссас К. (Troussas С.), Хрисафріаді К. (Chrysafiadi K.), Вiрву М. (Virvou М.), які досліджували персоналізоване навчання через стереотипну модель студента [22]; Мюррей М.К. (Murray M.C.), Перес Дж. (Pérez J.), які порівнювали адаптивне та традиційне навчання [19]; ДеМінк Карфей (DeMink-Carthew J.), Неткох C. (Netcoh S.), Фарбер K. (Farber K.), які вивчали потенціал розвитку самосвідомості студентів через персоналізоване навчання [14].

Аналіз даних праць вказує на актуальність впровадження персоналізованого навчання і окремі його проблеми успішно вирішуються, проте вважаємо за потребу продовжити наукові пошуки. Зокрема, важливим є вирішення питань щодо проєктування персоналізованого навчання у закладі вищої освіти, побудови моделі такого навчання, визначенні принципів та педагогічних умов його реалізації.

\section{III Результати}

Метод наукового моделювання завжди застосовується тоді, коли необхідно визначити оптимальні шляхи впровадження інновації. Педагогічна модель дає змогу побачити освітній процес загалом та його складові, врахувати всі етапи ефективної реалізації тієї чи іншої інновації, перевірити логіку зв'язків в системі.

Аналіз науково-педагогічної літератури та власний досвід побудови педагогічних моделей дав змогу побудувати модель реалізації педагогічного потенціалу персоналізованого навчання студентів закладу вищої освіти (рис. 2).

Основні структурно-фуннціінальні компоненти містять: мету реалізації, принципи процесу реалізації, основні етапи процесу реалізації з їх змістом, педагогічні умови реалізації персоналізованого навчання студентів закладу вищої освіти та результат.

Мета як мотиваційна складова в даному випадку вказує на потребу удосконалення освітнього процесу шляхом персоналізації процесу освіти, побудови індивідуальної траєкторії навчання, збільшення ролі соціальної участі студента.

Принципи є основними правилами і закономірностями реалізації та функціонування моделі, які формують структуру та логіку освітнього процесу. Вони ссрормульовані в першу чергу на основі загальнодидактичних принципів навчання з врахуванням специфіки моделі, що розробляється:

Принцип свідомості та активності вказує на те, що неможливо навчити студента, якщо він не має бажання вчитись. В даному принципі повністю відображено мотивацію навчання. Важливу роль в персоналізованому навчанні відіграє активність студента, його творчий підхід до вирішення проблеми, впевненість у власних силах, вміння брати на себе відповідальність, приймати рішення. При цьому персоналізоване навчання заохочує студентів усвідомлювати не тільки власні ідеї, але й те, як ці ідеї можуть розвиватись та удосконалюватись за рахунок впливу ідей інших студентів. Це питання 
соціальної участі, що є невід'ємним компонентом в умовах персоналізованого навчання.

Принцип доступності та зрозумілості визначає потребу враховувати індивідуальні особливості особистості, їх готовність до роботи (наприклад, в інформаційно-освітньому середовищі 3ВО). Крім того, при проектуванні персоналізованого навчання потрібно орієнтуватись також на те, щоб вона була зрозумілою для студента. В даному випадку також потрібно враховувати те, що будь-яка діяльність повинна мати певний сенс, щоб студент розумів для чого він виконує те чи інше завдання. Таким чином, буде можна досягнути не просто запам'ятовування, а розуміння навчального матеріалу.

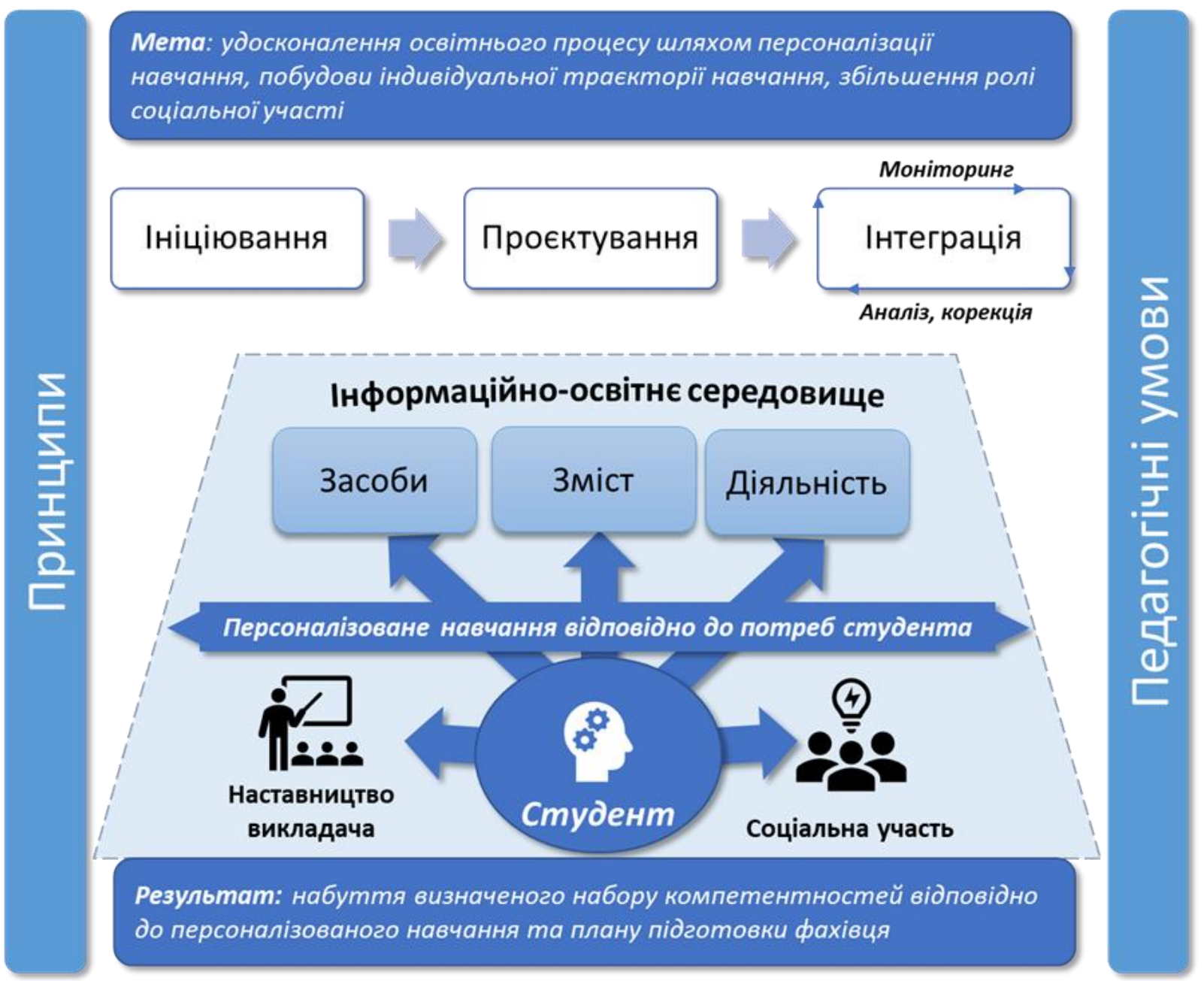

Рис. 2. Модель реалізації персоналізованого навчання студента

Принцип гнучкості та адекватності передбачає готовність освітнього процесу до будь-яких змін і відповідність сучасним вимогам. Тому планування персоналізованого навчання студента потрібно здійснювати таким чином, щоб можна було вносити відповідні зміни з огляду на мінливі зовнішні та внутрішні чинники. Наприклад, освітяни були не готові до карантинних обмежень, які вимушено були застосовані до закладів освіти у зв'язку з поширенням коронавірусу. Це спричинило своєрідний «освітній колапс», коли студенти та школярі були змушені навчатись дистанційно, не маючи при цьому відповідних засобів та можливостей для навчання (відсутність зв'язку, обладнання, програмних засобів тощо). Відповідно, це значно вплинуло на якість освіти і підготовку фахівців загалом.

Принцип послідовності та дозованості освітнього контенту вказує на поступове, крок за кроком, вивчення наступного матеріалу у тісному зв'язку з попередньо вивченим. При цьому також варто дозувати освітній контент, урізноманітнюючи його різними формами подання.

Принцип соціальної участі акцентує увагу на тому, що персоналізоване навчання обов'язково передбачає групову діяльність, де є місце обговоренням, дискусіям, спільна робота над проєктами тощо. При цьому студенти працюють як у групах, так і з викладачем, який допомагає розвивати 
проблему чи ідею, спланувати подальші дії, які призведуть до потрібного результату. Ефективна генерація ідей завжди відбувається через відношення з іншими, через діалог, обговорення, пропозиції тощо. Реальну мотивацію надає усвідомлення того, що проблема спільна, адже саме завдяки силі співробітництва можна досягти значних успіхів.

Принцип контролю та самоконтролю особливо важливий при організації персоналізованого навчання, оскільки передбачає постійний самоконтроль своєї освітньої траєкторії з боку студента та контроль з боку викладача. В даному випадку студенту також потрібно планувати свою навчальну діяльність щоб досягти поставленої мети. Викладач допомагає спланувати навчальну діяльність, а також здійснює моніторинг та оцінює отриманий результат. Основна мета - допомогти стати студентам більш самостійними, керувати своєю діяльністю, ставити цілі та досягати їх.

В моделі також пропонуємо етапи процесу реалізації персоналізованого навчання студента в 3ВО, які відображають динаміку його функціонування. Етапи відображають низку логічно зв'язаних задач, вирішення яких забезпечує досягнення мети.

Етап 1. Ініціювання. На даному етапі фрормується загальна ідея реалізація персоналізованого навчання в освітньому процесі. Відбувається уточнення стратегічної мети процесу впровадження, яка в подальшому буде запускати всі механізми моделі, планування та проектування процесу. Важливість даного етапу полягає в тому, що потрібно визначити головні напрямки стратегії впровадження персоналізованого навчання і основні пріоритети розвитку освітнього процесу.

Головна мета впровадження персоналізованого навчання базується на ідеї, що індивідуальна освітня траєкторії студента обов'язково повинна включати не тільки його інтереси та індивідуальні задатки, але й передбачати соціальну участь у процесі навчання, де викладачу відводиться роль партнера та наставника.

Етап 2. Діагностика та проєктування. Реалізації персоналізованого навчання передує моніторинг необхідних засобів та технологій, які можуть бути застосовані у процесі навчання. Також на даному етапі доцільно проаналізувати навчальний план підготовки фрахівця, компетентності, які будуть набуватись в процесі навчання, виявити інтереси студентів та спрогнозувати проблеми, які можуть виникнути в ході реалізації персоналізованого навчання. В даному випадку можна застосувати технологію SWOT-аналізу для виявлення ризиків та проблем, які можуть виникнути на шляху впровадження персоналізованого навчання.

Етап 3. Інтеграція. Передбачає безпосередньо реалізацію персоналізованого навчання і $\epsilon$ безперервним замкненим циклом, який включає моніторинг, аналіз та корекцію освітнього процесу. При цьому необхідно передбачити можливість подальшого розвитку та модернізації освітнього процесу на основі виявлених проблем чи нових можливостей персоналізованого навчання.

Модель також містить педагогічні умови реалізації персоналізованого навчання, які забезпечують ефективність освітнього процесу. До них відносимо питання нормативно-змістового, соціальнопсихологічного та організаційно-педагогічного забезпечення даного процесу.

До першої групи умов відноситься нормативні документи освітнього процесу, змістове наповнення навчального курсу, методичний супровід.

Друга група передбачає готовність студентів до персоналізованого навчання та готовність викладачів організувати таке навчання. Сюди також відносимо такі надзвичайно важливі компоненти як інфрормаційна культура учасників освітнього процесу, мотивація та психологічний супровід.

Третя група вказує на важливість матеріально-технічного та педагогічного забезпечення. Сюди відноситься апаратне та програмне забезпечення, інформаційно-освітнє середовище 3ВО, кадрове забезпечення, наявність технічних спеціалістів тощо.

Інфрормаційно-освітнє середовище базується на трьох компонентах - засоби, зміст, діяльність. Для організації навчальної діяльності та використання змісту потрібні засоби, які засновані на сукупності програмно-технічного забезпечення. Організація діяльності може також відбуватись із залученням зовнішніх сервісів, які знаходяться за межами інформаційно-освітнього середовища.

Інформаційно-освітнє середовище може бути організовано за допомогою відповідних освітніх програмних систем, наприклад, Moodle, Google Classroom, iSpring, Atutor, llias, Edmodo, Kiddom тощо. Ці середовища дають змогу встановити ціль навчання, керувати освітньою траєкторію, персоналізувати навчальний процес, керувати змістом та здійснювати комунікацію, що забезпечує активну соціальну 
взаємодію в онлайновому середовищі. Персоналізоване навчання може бути ефективнішим завдяки інтеграції зовнішніх вебсервісів до відповідної системи управління навчанням, які покращують експлуатацію та функціональність системи загалом і дають змогу досягати освітніх цілей.

Нині в закладах освіти переважно використовують платформу Moodle [18], оскільки вона є безкоштовною і функціонал якої може забезпечити різні моделі онлайнового навчання. Крім того, Moodle стала фрактичним стандартом для більшості закладів освіти світу [13]. Електронні освітні курси, розроблені в системі мають всі можливості для реалізації персоналізованого навчання і створення навчального середовища студента. Система має ідентифікацію та можливість персоналізувати власне середовище, дає змогу розробляти курси з урахуванням рівня підготовки, потреб та здібностей студента, може бути змінена за рахунок інтеграції зовнішніх вебсервісів, має інструменти контролю і самоконтролю тощо. Персоналізація навчання в даному середовищі може бути забезпечена такими функціями системи як репозиторій компетентностей і блок прогресу компетентностей, які дають змогу відстежувати власний прогрес. Для викладача - це можливість здійснювати контроль над навчальною діяльністю студента, виявляти труднощі у навчанні та вчасно надавати допомогу.

\section{IV Обговорення}

Загалом існують суттєві риси та головні тези, які визначають персоналізоване навчання і дають змогу здійснити його моделювання:

- використання персоналізованого навчання як основної технології дає змогу підвищити мотивацію студентів, сприяє їх самовизначенню та задовольняє їх освітні потреби [8];

- індивідуальна траєкторія навчання відповідає освітнім цілям, інтересам, талантам та прагненням студента, в ході якого він бере активну участь у проєктуванні свого навчання і бере відповідальність за нього $[15,16]$;

- адаптоване навчання, яке пристосоване до стилю навчання особистості, а також дає змогу взаємодіяти зі студентами та варіювати у відповідності до цієї взаємодії, призводить до кращих результатів навчання [19, 22];

- системи електронного навчання дають змогу побудувати ефективне інформаційно-освітнє середовище та значно покращити адаптованість навчання на основі механізмів, які враховують інтереси та вподобання студентів, дають змогу обирати навчальну траєкторію, будувати освітній процес [7, 10, 9];

- персоналізоване навчання $€$ самоосвітньою діяльністю, що забезпечує потребу в особистому просторі, саморозвитку, здійснення вибору та можливість контролю свого прогресу та досягнень, індивідуальність, унікальність та самостійність [14].

Аналіз літератури вказує на те, що незважаючи на велику кількість праць щодо персоналізованого навчання, його потенціал залишається вивченим не повною мірою. Продовжується накопичення досвіду щодо впровадження персоналізованого навчання, використання інсормаційно-комунікаційних технологій, розвитку адаптивних технологій організації освітнього процесу.

\section{V Висновки}

Розроблена нами педагогічна модель персоналізованого навчання $є$ основою для проєктування освітнього процесу в закладах вищої освіти, в яких впроваджуються концепції адаптивного, інклюзивного та змішаного навчання. Адаптивне навчання 3 використанням інформаційнокомунікаційних технологій має ряд переваг, надає студентам широкі можливості вільного вибору власної освітньої траєкторії при вивченні певної теми чи курсу загалом, передбачає диференційований підхід, підвищує оперативність та об'єктивність контролю та оцінки навчальної діяльності студента. Інклюзивне навчання передбачає застосування особистісно орієнтованих методів навчання, врахування індивідуальних особливостей студента, створення інклюзивного освітнього середовища та застосування принципів персоніфікованого дизайну навчального середовища. Змішане навчання передбачає розумну комбінацію онлайнового та традиційного навчання і активне використання технологій навчання, які дають змогу отримати нові знання та сформувати нові навички. Крім того, змішане навчання передбачає поєднання різних технологій та підходів до навчання, які передбачають самостійне 
вивчення та групову роботу, але в кінцевому варіанті всі вони спрямовані на досягнення відповідних освітніх цілей студента.

Як видно, концепції адаптивного, інклюзивного та змішаного навчання мають однакові ознаки - це орієнтація на освітні потреби (в разі інклюзивного навчання, особливі освітні потреби), здібності та можливості особистості. Тому, центральною фігурою пропонованої нами моделі $\epsilon$ студент і процес персоналізованого навчання вибудовується в залежності від його освітніх потреб, задатків та інтересів, що забезпечує мотивацію навчання, високий рівень підготовки та соціалізації особистості.

\section{Бібліографрічні посилання}

1. Баранова О. В., Артюх В.О. Персоналізація навчання та новітні технології як відповідь на глобальні виклики сучасності. Научные труды SWorld. 2016. Вып. 45. Т. 5. С. $28-33$.

2. Дем'яненко В.M. Освітні сервіси персоналізованого навчання. Комп'ютер у школі та сім'ї. №5. 2017. C.19-22. URL: https://core.ac.uk/download/pdf/144470807.pdf.

3. Кухаренко В. М. Тьютор дистанційного та змішаного навчання : навч. посібник. Харків : Міленіум, 2019. 307 c. URL: http://repository.kpi.kharkov.ua/bitstream/KhPI-Press/42981/3/Book_2019_Kukharenko_Tiutor.pdf.

4. Медведєва М. О. Дослідження передумов впровадження особистісно орієнтованого навчання теоретичних основ інсорматики. Вісник Луганського національного університету імені Тараса Шевченка, 2010. № 1 (188). С. 173-185.

5. Осадча К., Осадчий В., Спірін О., Круглик В. Реалізація індивідуалізації та персоналізації навчання засобами Moodle. Молодь і ринок. №1 (187). 2021. С.38-43. http://mir.dspu.edu.ua/article/view/228274/227419.

6. Якубов С. Персоналізоване навчання в загальноосвітній школі: основні визначення та шлях до впровадження. Директор школи. 9 (117). 2016. С.59-72.

7. Aeiad E., Meziane F. An adaptable and personalised E-learning system applied to computer science Programmes design. Education and Information Technologies. 24, 2019. 1485-1509. https://doi.org/10.1007/s10639-018-9836-x.

8. Alamri H., Lowell V., Watson W., Watson S.L. Using personalized learning as an instructional approach to motivate learners in online higher education: Learner self-determination and intrinsic motivation. Journal of Research on Technology in Education, 52 (3), 2020. 322-352, DOI: 10.1080/15391523.2020.1728449.

9. Atif Y., Benlamri R., Berri, J. Learning Objects Based Framework for Self-Adaptive Learning. Education and Information Technologies. 8, 2003. 345-368. https://doi.org/10.1023/B:EAIT.0000008676.64018.af.

10. Benhamdi S., Babouri A., Chiky R. Personalized recommender system for e-Learning environment. Education and Information Technologies, 22, 2017. 1455-1477. https://doi.org/10.1007/s10639-016-9504-y.

11. Bernacki, M. L., Walkington, C. The role of situational interest in personalized learning. Journal of Educational Psychology, 110(6). 2018. 864-881. https://doi.org/10.1037/edu0000250

12. Bray B., McClaskey K. Make Learning Personal. The What, Who, WOW, Where, and Why. Corwin, 2015. 288 p.

13. Campo M., Amandi A., Biset J.C. A software architecture perspective about Moodle flexibility for supporting empirical research of teaching theories. Education and Information Technologies. 26, 2021. 817-842. https://doi.org/10.1007/s10639-020-10291-4.

14. DeMink-Carthew J., Netcoh S., Farber K. Exploring the Potential for Students to Develop Self-Awareness through Personalized Learning. The Journal of Educational Research. 113 (3), 2020. 165-176, DOl: 10.1080/00220671.2020.1764467.

15. DeMink-Carthew J., Olofson M.W., LeGeros L., Netcoh S., Hennessey S. An Analysis of Approaches to Goal Setting in Middle Grades Personalized Learning Environments. Research in Middle Level Education Online. 40 (10), 2017. 1-11, DOI: 10.1080/19404476.2017.1392689.

16. Drexler W. The networked student model for construction of personal learning environments: Balancing teacher control and student autonomy. Australasian Journal of Educational Technology, 26(3). 2010. https://doi.org/10.14742/ajet.1081.

17. Ellis G. Grand challenges for engineering. IEEE Engineering Management Review, 37(1), 2009. 3-3.

18. Mintii I. Using Learning Content Management System Moodle in Kryvyi Rih State Pedagogical University educational process. CEUR Workshop Proceedings. 2020. 293-305. http://ceur-ws.org/Vol-2643/paper17.pdf.

19. Murray M.C., Pérez J. Informing and Performing: A Study Comparing Adaptive Learning to Traditional Learning. Informing Science: The International Journal of an Emerging Transdiscipline. Volume 18. 2015. pp. 111-125. DOl: https://doi.org/10.28945/2165.

20. Osadchyi V., Krasheninnik I., Spirin O., Koniukhov S., Diuzhykova T. Personalized and Adaptive ICT-Enhanced Learning: A Brief Review of Research from 2010 to 2019. CEUR Workshop Proceedings. 2020. 547-558. URL: http://ceur-ws. org/Vol2732/20200559.pdf

21. Puliaieva A., Kravtsova L., Zaytseva T. Formation of Personalized Learning Path for Foreign Students Based on the MOODLE E-Learning Platform Using SCORM-Package. CEUR Workshop Proceedings. 2020. 839-853. http://ceurws.org/Vol-2732/20201129.pdf

22. Troussas C., Chrysafiadi K., Virvou M. Personalized tutoring through a stereotype student model incorporating a hybrid learning style instrument. Education and Information Technologies, 26. 2021. 2295-2307. https://doi.org/10.1007/s10639020-10366-2. 
23. Walkington C., Bernacki M.L. Appraising research on personalized learning: Definitions, theoretical alignment, advancements, and future directions. Journal of Research on Technology in Education, 52 (3), 2020. 235-252. DOl: 10.1080/15391523.2020.1747757.

\section{References}

1. Baranova, O. V., Artiukh, V.O. (2016), Personalizatsiia navchannia ta novitni tekhnolohii yak vidpovid na hlobalni vyklyky suchasnosti, Nauchnye trudy SWorld, Iss. 45, T. 5, pp. 28-33. [in Ukrainian]

2. Demianenko, V.M. (2017), Osvitni servisy personalizovanoho navchannia, Computer at School and at Home, №5, pp.1922. [in Ukrainian]

3. Kukharenko, V. M. (2019), Tiutor dystantsiinoho ta zmishanoho navchannia, Kharkiv, Milenium, 307 p. [in Ukrainian]

4. Medvedieva, M. O. (2010), Doslidzhennia peredumov vprovadzhennia osobystisno oriientovanoho navchannia teoretychnykh osnov informatyky, Bulletin of Luhansk Taras Shevchenko National University, № 1 (188), pp. 173-185. [in Ukrainian]

5. Osadcha, K., Osadchyi, V., Spirin, O., Kruhlyk, V. (2021), Realizatsiia indyvidualizatsii ta personalizatsii navchannia zasobamy Moodle, Youth \& market, №1 (187), pp.38-43. [in Ukrainian]

6. Yakubov, S. (2016), Personalizovane navchannia $v$ zahalnoosvitnii shkoli: osnovni vyznachennia ta shliakh do vprovadzhennia, Dyrektor shkoly, 9 (117), pp.59-72. [in Ukrainian]

7. Aeiad, E., Meziane, F. (2019), An adaptable and personalised E-learning system applied to computer science Programmes design, Education and Information Technologies, Iss. 24, pp.1485-1509. DOI: https://doi.org/10.1007/s10639-018-9836-x.

8. Alamri, H., Lowell, V., Watson, W., Watson, S.L. (2020), Using personalized learning as an instructional approach to motivate learners in online higher education: Learner self-determination and intrinsic motivation, Journal of Research on Technology in Education, 52 (3), pp.322-352. DOI: 10.1080/15391523.2020.1728449.

9. Atif, Y., Benlamri, R., Berri, J. (2003), Learning Objects Based Framework for Self-Adaptive Learning, Education and Information Technologies, 8, pp. 345-368. DOI: https://doi.org/10.1023/B:EAIT.0000008676.64018.af.

10. Benhamdi, S., Babouri, A., Chiky, R. (2017), Personalized recommender system for e-Learning environment, Education and Information Technologies, 22, pp.1455-1477. DOI: https://doi.org/10.1007/s10639-016-9504-y.

11. Bernacki, M. L., Walkington, C. (2018), The role of situational interest in personalized learning, Journal of Educational Psychology, 110(6), pp.864-881. DOI: https://doi.org/10.1037/edu0000250

12. Bray, B., McClaskey, K. (2015), Make Learning Personal. The What, Who, WOW, Where, and Why, Corwin, 288 p.

13. Campo, M., Amandi, A., Biset, J.C. (2021), A software architecture perspective about Moodle flexibility for supporting empirical research of teaching theories, Education and Information Technologies, 26, pp.817-842. DOI: https://doi.org/10.1007/s10639-020-10291-4.

14. DeMink-Carthew, J., Netcoh, S., Farber, K. (2020), Exploring the Potential for Students to Develop Self-Awareness through Personalized Learning, The Journal of Educational Research, 113 (3), pp.165-176. DOl: 10.1080/00220671.2020.1764467.

15. DeMink-Carthew, J., Olofson, M.W., LeGeros, L., Netcoh, S., Hennessey, S. (2017), An Analysis of Approaches to Goal Setting in Middle Grades Personalized Learning Environments, Research in Middle Level Education Online, 40 (10), pp.111. DOI: $10.1080 / 19404476.2017 .1392689$.

16. Drexler, W. (2010), The networked student model for construction of personal learning environments: Balancing teacher control and student autonomy, Australasian Journal of Educational Technology, 26(3). DOl: https://doi.org/10.14742/ajet.1081.

17. Ellis, G. (2009), Grand challenges for engineering, IEEE Engineering Management Review, 37(1), pp.3-3.

18. Mintii, I. (2020), Using Learning Content Management System Moodle in Kryvyi Rih State Pedagogical University educational process, CEUR Workshop Proceedings, pp. 293-305.

19. Murray, M.C., Pérez, J. (2015), Informing and Performing: A Study Comparing Adaptive Learning to Traditional Learning, Informing Science: The International Journal of an Emerging Transdiscipline, Volume 18, pp. 111-125. DOI: https://doi.org/10.28945/2165.

20. Osadchyi, V., Krasheninnik, I., Spirin, O., Koniukhov, S., Diuzhykova, T. (2020), Personalized and Adaptive ICT-Enhanced Learning: A Brief Review of Research from 2010 to 2019, CEUR Workshop Proceedings, pp. 547-558.

21. Puliaieva, A., Kravtsova, L., Zaytseva, T. (2020), Formation of Personalized Learning Path for Foreign Students Based on the MOODLE E-Learning Platform Using SCORM-Package, CEUR Workshop Proceedings, p.839-853.

22. Troussas, C., Chrysafiadi, K., Virvou, M. (2021), Personalized tutoring through a stereotype student model incorporating a hybrid learning style instrument, Education and Information Technologies, Iss.26. pp. 2295-2307. DOI: https://doi.org/10.1007/s10639-020-10366-2. 
23. Walkington, C., Bernacki, M.L. (2020), Appraising research on personalized learning: Definitions, theoretical alignment, advancements, and future directions, Journal of Research on Technology in Education, Iss. 52 (3), pp. 235-252. DOl: 10.1080/15391523.2020.1747757.

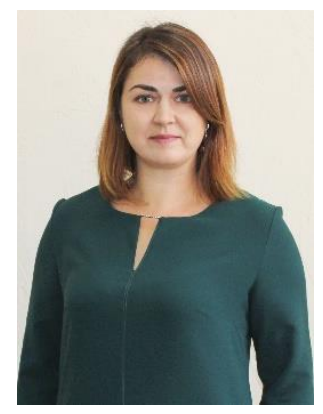

Ткачук Галина Володимирівна.

доктор педагогічних наук, доцент, професор кафедри інформатики і інформаційно-комунікаційних технологій,

Уманський державний педагогічний університет імені Павла Тичини

адреса: вул. Садова, Умань, 20300

Тел. +380969169399. E-mail: tkachuk.g.v@udpu.edu.ua

\section{Tkachuk Halyna Volodymyrivna}

Doctor of Pedagogical Sciences, Docent,

Professor at the Department of Informatics and Information and Communication Technology

Pavlo Tychyna Uman State Pedagogical University,

Adress: 28 Sadova str., Uman, Cherkassy region, Ukraine, 20300

Phone: +380969169399. E-mail: tkachuk.g.v@udpu.edu.ua

ORCID: https://orcid.org/0000-0002-6926-1589

Researcher ID: https://publons.com/researcher/1773042/halyna-tkachuk

Scopus ID: https://www.scopus.com/authid/detail.uri?authorld=57219986242

\section{Citation (APA):}

Tkachuk H. V. (2021). Model of realization of personalized learning of students of higher education institution. Engineering and

Educational Technologies, 9 (3), 8-17. doi: https://doi.org/10.30929/2307-9770.2021.09.03.01

\section{Цитування (ДСТУ 8302:2015):}

Ткачук Г. В. Модель реалізації персоналізованого навчання студентів закладу вищої освіти / Інженерні та освітні технології. 2021. T. 9. № 3. C. 8-17. doi: https://doi.org/10.30929/2307-9770.2021.09.03.01

Обсяг статmi: сторінок - 10 ; умовних друк. аркушів - 1,448. 